\title{
OPTIMASI BIOPROSES MODIFIKASI PERMUKAAN SERAT UNTUK PENINGKATAN KEKUATAN KERTAS
}

\author{
Taufan Hidayat ' , Nina Elyani, Chandra Apriana Purwita \\ Balai Besar Pulp dan Kertas, Jl. Raya Dayeuhkolot No. 132 Bandung \\ 1 taufanhidayat@gmail.com
}

Diterima : 25 Februari 2014, Revisi akhir : 5 Mei 2014, Disetujui terbit : 30 Mei 2014

\section{BIOPROCESS OPTIMIZATION OF FIBER SURFACE MODIFICATION FOR PAPER STRENGTH DEVELOPMENT}

\begin{abstract}
Fiber surface modification is a main process to improve paper quality. It is usually done mechanically through refining process. In this research the modification was done microbiologically by using Acetobacter xylinum. In principle, this process is carried out by growing bacterial cellulose on the fiber surface, which is similar to fibrillation by mechanical action. The modification was done at the short fibers at 5 duration reaction times and 4 level agitation speeds. The experiments were conducted in a 75 liter active volume bioreactor filled with a liquid inorganic media, $0.75 \%$ pulp consistency, at $30^{\circ} \mathrm{C}$ temperature, and $\mathrm{pH}$ 5.5. The washed pulp was then turned into sheets for testing purposes. The experiments show that at $37.5 \mathrm{~Hz}$ agitation speed and 1-3 hours reaction time, the paper strength and structure improve effectively. In addition, this optimized process also shows a potential energy saving up to $17.24 \%$ at agitation speed of $25,0 \mathrm{~Hz}$.
\end{abstract}

Keywords: fiber surface modification, Acetobacter xylinum, paper strength, short fibers

\begin{abstract}
ABSTRAK
Modifikasi permukaan serat adalah proses inti pembuatan kertas untuk meningkatkan kualitas kertas. Pada umumnya modifikasi permukaan serat dilakukan secara mekanis melalui proses penggilingan. Pada penelitian ini modifikasi permukaan serat dilakukan secara mikrobiologis menggunakan Acetobacter xylinum. Proses ini berlangsung dengan cara menumbuhkan bakteri pembentuk selulosa pada permukaan serat sehingga serat terfibrilasi. Penelitian dilakukan pada serat pendek dengan variasi 5 durasi waktu reaksi dan 4 tingkat kecepatan agitasi. Proses modifikasi dilakukan dalam bioreaktor dengan volume aktif 75 liter menggunakan media anorganik cair, pada konsistensi pulp $0,75 \%$, suhu $30^{\circ} \mathrm{C}$, dan $\mathrm{pH}$ 5,5. Pulp hasil reaksi dicuci kemudian dibuat lembaran untuk diuji karakteristik fisiknya. Hasil pengamatan menunjukkan bahwa pada kondisi kecepatan agitasi $37,5 \mathrm{~Hz}$ dan waktu inkubasi 1-3 jam, bioproses modifikasi serat efektif untuk meningkatkan kekuatan kertas, memperbaiki struktur lembaran kertas, dan berpeluang menghemat energi sebesar 17,24\% pada kecepatan agitasi 25,0 Hz.
\end{abstract}

Kata kunci: modifikasi permukaan serat, Acetobacter xylinum, kekuatan kertas, serat pendek

\section{PENDAHULUAN}

Secara konvensional kekuatan lembaran kertas dapat dibangun dengan penggunaan serat panjang, refining serat, dan penambahan bahan kimia penguat. Masing-masing cara memiliki kekurangan dan kelebihan. Serat panjang sangat efektif dalam membangun kekuatan, tetapi harganya mahal dan masih impor. Refining adalah teknik paling mapan yang digunakan untuk membangun kekuatan lembaran. Teknik ini satusatunya cara yang memodifikasi sifat fisik serat. Akan tetapi kemampuan berbagai jenis serat untuk dimodifikasi dengan cara ini berbeda-beda. 
Kendala utama dalam refining adalah konsumsi energinya yang cukup besar, peringkat kedua di industri kertas sesudah pengeringan, dan bila terjadi refining berlebihan maka kertas tidak dapat dibentuk karena serat akan hancur. Bahan kimia juga cukup efektif untuk membangun kekuatan kertas, tetapi harganya mahal dan umumnya berdampak tidak ramah lingkungan pada air limbahnya, khususnya untuk aditif penguat jenis sintetis.

Dari ketiga cara peningkatan kekuatan kertas di atas, yang paling banyak dilakukan oleh industri adalah melalui proses refining. Pada dasarnya refining dilakukan dengan menggosok serat diantara permukaan rotor dan stator yang bersifat kasar dengan pola alur tertentu. Akibat gosokan ini terjadi perubahan fisik pada serat yang tadinya kaku dengan permukaan yang mulus, bentuk silindris, dan bagian tengah berlubang, menjadi serat yang lentur, pipih dan permukaannya berbulu. Bulu-bulu yang berukuran mikron ini disebut fibril, dan mikrofibrilasi ini sangat berguna saat serat dengan serat saling berikatan membentuk lembaran kertas. Mikrofibrilasi memperluas permukaan serat sehingga menambah jumlah ikatan hidrogen yang terbentuk sehingga terjadi peningkatan kekuatan kertas yang signifikan sesudah refining. Proses refining adalah proses kedua terbesar di industri kertas dalam hal konsumsi energi.

Berbagai penelitian terdahulu menunjukkan bahwa, fibrilasi permukaan serat juga dapat dilakukan dengan memanfaatkan mikroba tertentu seperti Acetobacter atau Gluconobacter. Fibril yang terbentuk berukuran nano dan peristiwa ini disebut nanofibrilasi. Kebanyakan pada penelitian-penelitian tersebut, nanofibrilasi dimanfaatkan untuk meningkatkan mutu komposit, yaitu campuran serat selulosa yang terfibrilasi secara nano dengan bahan-bahan lain. Dengan nanofibrilasi ini, peningkatan kinerja komposit dapat diperoleh secara signifikan (Vitta dan Thiruvengadam, 2012). Prinsip dasar bioproses modifikasi permukaan serat adalah sebagai berikut; Serat dalam media kultur bakteri diinokulasi dengan bakteri penghasil selulosa, kemudian serat diekstrak kembali dari media kultur tersebut (Chen dkk., 2010).

Bioproses modifikasi permukaan serat pada dasarnya adalah upaya penumbuhan bakteri pembentuk selulosa pada permukaan serat. Bacterial cellulose dapat disintesis oleh bakteri yang termasuk ke dalam genus Acetobacter,
Rhizobium, Agrobacterium, Aerobacter, Achromobacter, Azotobacter, Rhizobium, Sarcina, Salmonella, dan Escherichia. Dari genus bakteri tersebut, yang paling efisien dalam menghasilkan selulosa adalah Acetobacter xylinum. Bakteri ini dapat disolasi dari berbagai sumber seperti limbah buah nenas (Pratama dkk., 2013), limbah padat serat (Cavka dkk., 2013), dan cuka rumah (Castro dkk., 2012). Tingkat kemurnian selulosa yang dihasilkan oleh bakteri lebih tinggi dibandingkan dengan selulosa yang dihasilkan dari tumbuhan (Raghunathan, 2013). Hal ini disebabkan oleh selulosa tumbuhan berada dalam ikatan dengan bahan kimia lain seperti lignin dan hemi selulosa sehingga harus dipisahkan.

Bacterial cellulose memiliki karakteristik istimewa seperti derajat polimerisasi, indeks kristalinitas, ketahanan tarik, dan kapasitas penyerap air yang tinggi dibandingkan dengan selulosa tumbuhan (Chawla dkk.,2009). Oleh karena itu bacterial cellulose telah digunakan secara luas di berbagai bidang seperti industri kertas, elektronik, dan rekayasa jaringan (Torres dkk., 2012). Selain itu bacterial cellulose dapat juga digunakan di bidang akustik dan peralatan biomedik (Nge, dkk., 2010). Aplikasi bacterial cellulose di industri kertas juga sudah cukup banyak diteliti, antara lain sebagai aditif yang dapat memperbaiki kekuatan dan sifat permukaan kertas (Surma-Slusarska, 2008), lembaran Bacterial cellulose sebagai kertas perkamen (Suwannapinunt, 2007), dan peretensi bahan pengisi (Basta dan El-Saied, 2009).

Produksi bacterial cellulose oleh bakteri $A$. xylinum dapat dihasilkan melalui kultur pada kondisi statis maupun dinamis. Untuk produksi bacterial cellulose pada kondisi statis mempunyai beberapa kekurangan seperti membutuhkan lebih banyak ruang dan tenaga kerja, hal ini menyebabkan produksi membutuhkan investasi yang lebih mahal. Oleh karena itu, untuk produksi bacterial cellulose secara komersial, kondisi produksi teragitasi lebih banyak digunakan. Berbagai jenis bioreaktor dengan konfigurasi yang berbeda telah diteliti untuk produksi bacterial cellulose pada kondisi teragitasi (Sani \& Dahman, 2009).

Bioproses modifikasi permukaan serat pada hakekatnya adalah proses produksi bacterial cellulose dalam bioreaktor, tetapi media reaksinya mengandung sejumlah serat sehingga bakteri pembentuk selulosa tumbuh juga di permukaan serat. Pertumbuhan bakteri pembentuk selulosa ini 
yang menyebabkan sifat permukaan serat berubah (termodifiksi) yang dalam sudut pandang proses pembuatan kertas hal ini tidak lain adalah peristiwa fibrilasi serat. Karena fibrilnya berukuran nano, maka proses fibrilasi bisa disebut nanofibrilasi. Perubahan teknik fibrilasi dari mikro (mekanis konvensional) ke nano (bioproses) akan disertai dengan perubahan jumlah ikatan hidrogen dalam lembaran kertas, sehingga diharapkan kekuatannya pun lebih tinggi. Selain peningkatan kekuatan kertas, teknik nanofibrilasi ini juga diharapkan bisa menurunkan konsumsi energi refining pada proses pembuatan kertas. Penelitian ini bertujuan melakukan modifikasi permukaan serat (nanofibrilasi) dalam bioreaktor jenis tangki berpengaduk dengan variabel waktu reaksi dan kecepatan agitasi yang mewakili kondisi laminar dan turbulen. Serat tersebut kemudian dipreparasi dan dibuat lembaran kertas sehingga kondisi bioreaksi dapat dilihat pengaruhnya terhadap sifat kertas.

\section{BAHAN DAN METODE}

Pada penelitian ini digunakan berbagai bahan berikut: kultur murni bakteri Acetobacter xylinum dari Laboratorium Mikrobiologi Teknik Kimia ITB; Media GYE yang terdiri dari glukosa $2 \%$, yeast extract $0,5 \%$, pepton $1 \%$, agar $2 \%$; media anorganik cair yang terdiri dari glukosa $1,5 \%$, ammonium sulfat $0,3 \%$, kalium dihidrogen fosfat $0,3 \%$, dinatrium dihidrogen fosfat $0,3 \%$, magnesium sulfat $0,08 \%$, ferosulfat $0,0005 \%$, asam borat $0,0003 \%$, niasin $0,00005 \%$, etanol teknis 0,6\%; kemudian Pulp Putih Serat Pendek (LBKP) yang berasal dari PT Kertas Padalarang.

Pada penelitian ini digunakan juga peralatan berikut: peralatan penanganan, penumbuhan, dan pemeliharaan bakteri; bioreaktor dengan variabel suhu, waktu, dan kecepatan agitasi; peralatan penanganan hasil bioreaksi; peralatan pembuatan lembaran kertas seperti disintegrator, PFI Mill, pembuat lembaran, pengepresan, dan pengeringan lembaran; peralatan pengujian kertas yang meliputi uji fisik dan kekuatan lembaran kertas.

Penelitian dilakukan melalui berbagai tahapan berikut : penyiapan inokulum Acetobacter xylinum berupa subkultur dalam media GYE dilanjutkan proses adaptasi ke media cair anorganik; pencampuran pulp serat pendek dengan media anorganik cair dalam bioreaktor; sterilisasi media berisi pulp dalam bioreaktor; proses bioreaksi dalam bioreaktor dimulai dengan inokulasi Acetobacter xylinum ke dalam bioreaktor volume $75 \mathrm{~L}$ dengan kondisi proses suhu $30^{\circ} \mathrm{C}, \mathrm{pH} 5,5$, konsistensi pulp $0,75 \%$, dosis inokulan $5 \%$. Variable proses adalah waktu reaksi $0 ; 1 ; 3 ; 5$; dan 8 jam; serta kecepatan agitasi 12,5; 25,0; 37,5; dan 50,0 Hz. Selanjutnya dilakukan pencucian pulp hasil bioreaksi untuk membersihkan media anorganik cair yang melekat pada serat; penguraian serat menggunakan disintegrator pada konsistensi 1,5\% dan 10000 putaran; penggilingan pulp menggunakan PFI Mill pada konsistensi 10 $\%$ dan 4300 putaran; dan akhirnya dilakukan proses pembentukan, pengepresan, dan pengeringan lembaran kertas. Sebagai akhir dari tahapan penelitian dilakukan pengkondisian dan pengujian lembaran kertas berdasarkan standar uji yang berlaku (SNI). Data-data ini kemudian dianalisis untuk melihat efektivitas dan efisiensi bioproses tersebut. Efektivitas dilihat dari indikasi peningkatan kekuatan kertas dan perbaikan struktur lembaran, sedangkan efisiensi dilihat dari peluang penghematan energi.

\section{HASIL DAN PEMBAHASAN}

\section{Pencapaian Freenes Stok}

Blanko adalah lembaran kertas yang dibuat dari pulp yang belum mengalami kontak dengan media cair anorganik tetapi sudah mengalami refining. Sedangkan pada saat pulp hasil refining sudah kontak singkat dengan media cair anorganik tetapi belum diinkubasi disebut 0 jam inkubasi. Freeness setelah proses refining pada berbagai kecepatan agitasi disajikan pada Gambar 1.

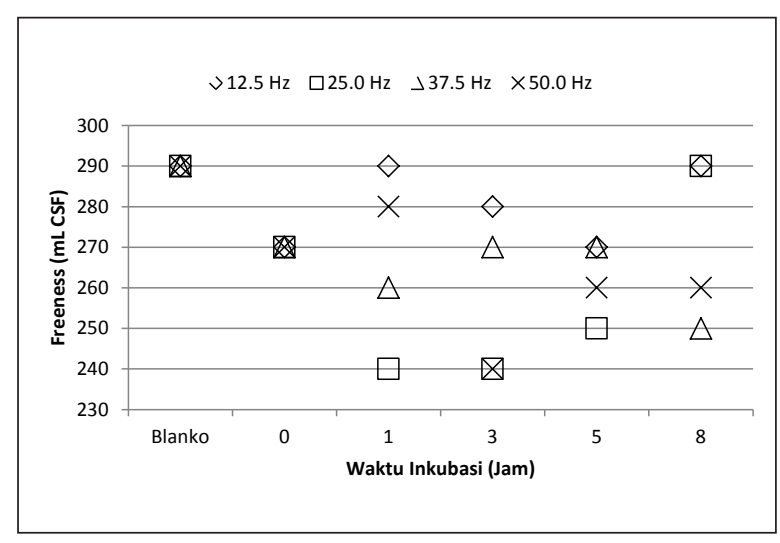

Gambar 1. Efek Inkubasi dan Agitasi terhadap Freeness 
Dari percobaan di laboratorium teramati bahwa freeness awal pulp hasil disintegrasi adalah $600 \mathrm{~mL}$ CSF. Selanjutnya untuk mencapai freeness $300 \mathrm{~mL}$ CSF diperlukan 6000 putaran PFI Mill. Teramati pula ternyata untuk pulp yang diinkubasi pencapaian freeness yang sama hanya memerlukan 4300 putaran. Hal ini menjadi indikasi penting adanya penghematan energi refining, karena untuk mencapai derajat giling yang sama diperlukan putaran PFI Mill yang lebih rendah. Pada Gambar 1 nampak semua perlakuan inkubasi cenderung menurunkan pencapaian freeness pada RPM PFI Mill yang sama. Ini berarti untuk mendapatkan freeness yang setara dengan blanko dapat diperoleh dengan menurunkan putaran PFI Mill atau waktu refining. Bila diasumsikan konsumsi energi bersifat linier terhadap pencapaian freeness maka dapat dihitung indikasi penghematan energi refining-nya sebagai berikut. Pencapaian freeness terendah terlihat pada waktu inkubasi $1-3$ jam sebesar $240 \mathrm{~mL}$ CSF. Sedangkan pada putaran yang sama nilai blanko freeness mencapai 290 $\mathrm{mL}$ CSF. Ini berarti potensi penghematan energi sebesar (290-240)/290 atau sekitar 17,4\%.

\section{Indeks Tarik}

Kecuali pada kecepatan agitasi 25,0 Hz, indikasi kecenderungan peningkatan indeks tarik kertas terlihat (Gambar 2), dan maksimal dicapai pada kecepatan agitasi $12,5 \mathrm{~Hz}$ dengan waktu inkubasi 1-3 jam. Peningkatan indeks tarik terjadi karena terbentuk fibril pada permukaan serat akibat aktivitas bakteri Acetobacter xylinum. Efek fibrilasi ini dengan sendirinya meningkatkan kekuatan ikatan antar serat, sehingga indeks tarik juga meningkat.

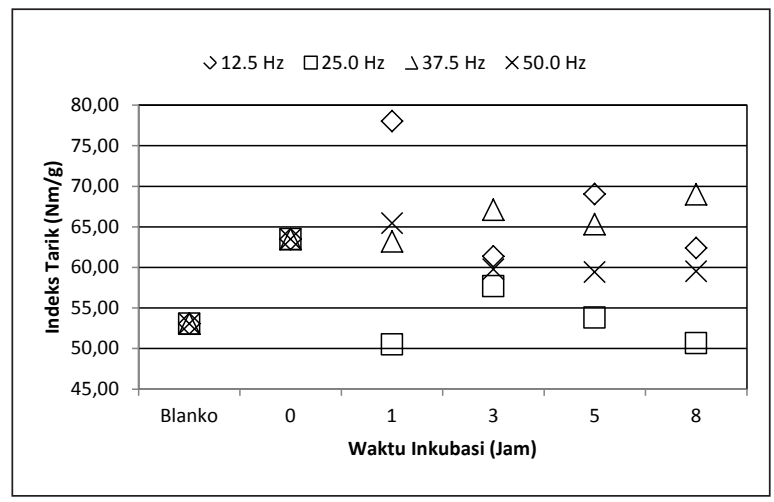

Gambar 2. Efek Inkubasi dan Agitasi terhadap Indeks Tarik
Kecenderungan terjadinya ketahanan tarik terbesar dicapai pada kecepatan agitasi terendah yaitu $12,5 \mathrm{~Hz}$ dan inkubasi 1-3 jam dan menurun kembali sesudah 3 jam inkubasi, kecuali untuk kecepatan $37,5 \mathrm{~Hz}$. Hal ini terjadi kemungkinan besar adalah karena pada kecepatan rendah, pembentukan nano selulosa (nano fibril) pada permukaan serat membentuk ikatan yang lebih baik dengan permukaan serat karena kondisi tenang (laminar). Sedangkan pada kecepatan tinggi (25,0 dan 50,0 Hz) kemungkinan daya ikat nano selulosa di permukaan serat tidak begitu kuat akibat gangguan turbulensi. Pada kecepatan yang lebih tinggi lagi $(37,5 \mathrm{~Hz})$ nanofibril yang lepas dari permukaan serat bisa terdeposisi kembali ke permukaan karena intensnya agitasi sehingga frekuensi tumbukan antar nano fibril dari bacterial cellulose dengan permukan serat semakin tinggi.

\section{Daya Regang}

Daya regang pada kecepatan agitasi $12,5 \mathrm{~Hz}$ cenderung konstan pada berbagai waktu inkubasi (Gambar 3). Meskipun kecepatan ini cenderung meningkatkan indeks tarik sebagaimana dibahas sebelumnya, namun pada kondisi laminar ini daya regang lebih dipengaruhi oleh sifat intrinsik seratnya.

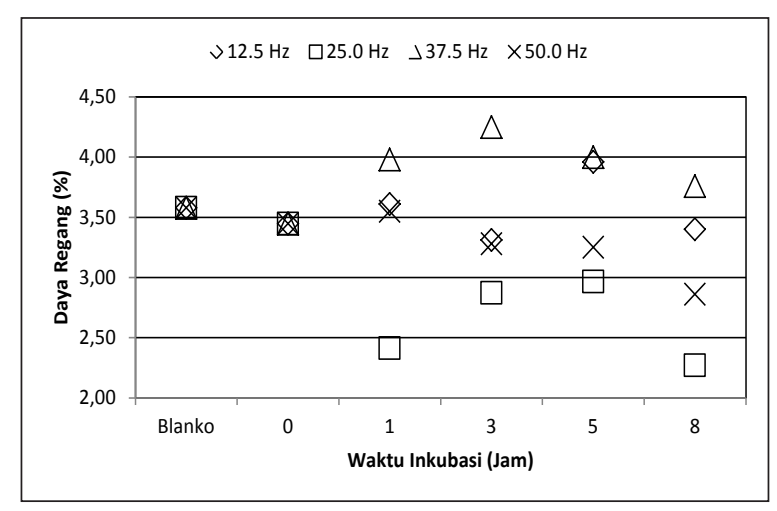

Gambar 3. Efek Inkubasi dan Agitasi terhadap Daya Regang

Pada saat kecepatan dinaikan menjadi $25,0 \mathrm{~Hz}$ maka dominasi sifat intrinsik menurun, kondisi reaksi lebih turbulen sehingga terjadi pelepasan nano fibril dari permukaan serat, maka daya regang cenderung turun. Fenomena yang sama terjadi pada kecepatan 50,0 Hz (Gambar 3). Tetapi, ada indikasi kecenderungan daya regang meningkat pada kecepatan $37,5 \mathrm{~Hz}$. Kemungkinan besar 
ini adalah pencapaian kondisi "kesetimbangan" antara dominasi sifat intrinsik serat dengan kondisi nanofibrilasi permukaan serat.

\section{Daya Serap Energi (TEA)}

TEA adalah ukuran kealotan lembaran kertas, yang merupakan kombinasi ketahanan tarik dan daya regang. Kecenderungan peningkatan kealotan kertas akibat inkubasi $1-3$ jam terlihat pada semua kecepatan (Gambar 4). Sesudah itu kemudian TEA menurun dengan meingkatnya waktu inkubasi. Daya regang berkontribusi dominan terhadap peningkatan kealotan sehingga pola kurvanya mirip dengan daya regang dengan urutan pencapaian tingkatan nilai TEA mengikuti urutan kecepatan 25,0; 50,0; 12,5 dan $37,5 \mathrm{~Hz}$

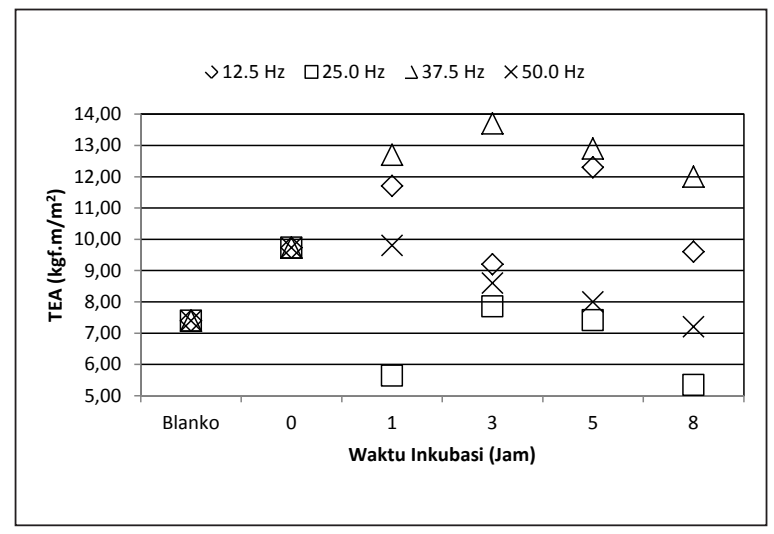

Gambar 4. Efek Inkubasi dan Agitasi terhadap TEA

\section{Indeks Retak}

Pada umumnya perlakuan inkubasi menyebabkan kecenderungan peningkatan indeks retak pada kecepatan agitasi 0,5-2,0 jam (Gambar 5). Nilai peningkatan indeks retak dicapai pada kecepatan $12,5 \mathrm{~Hz}$ dan waktu inkubasi 0,5-1,5 jam.

Indeks retak adalah ukuran kekuatan kertas menahan beban tegak lurus permukaan kertas, sangat dipengaruhi oleh ikatan antar serat. Seperti telah dibahas pada indeks tarik, kecepatan 12,5 $\mathrm{Hz}$ adalah kondisi laminer yang memungkinkan nanofibrilasi berkembang baik dipermukaan serat, sedikit kemungkinan terlepas kembali ke lingkungan cairannya akibat turbulensi. Oleh karena itu ikatan antar seratnya terbaik pada kecepatan ini. Sementara waktu inkubasi yang lebih lama tidak menambah kekuatan kertas karena pertumbuhan optimal nanofibril terjadi pada waktu inkubasi yang lebih pendek.

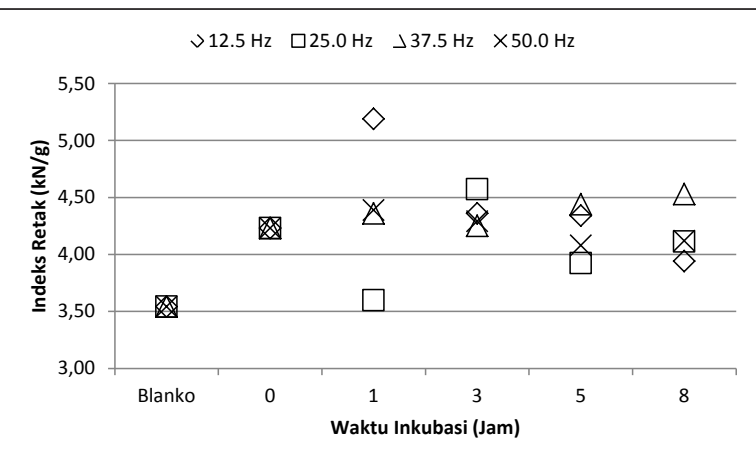

Gambar 5. Efek Inkubasi dan Agitasi terhadap Indeks Retak

\section{Indeks Sobek}

Berbeda dengan parameter kekuatan kertas lainnya, pada saat pengembangan kekuatan kertas, parameter seperti indeks tarik, daya regang, dan retak biasanya meningkat seiring dengan peningkatan proses refining. Tetapi indeks sobek berbeda, polanya meningkat dulu kemudian mencapai maksimal dan selanjutnya menurun. Karakter ini harus diwaspadai karena kalau hanya mempertimbangkan indeks tarik, ada kemunginan indeks sobeknya rendah. Oleh karena itu sangat mungkin terjadi perbedaan pencapaian titik maksimal indeks sobek dibandingkan dengan parameter kekuatan lainnya. Pada Gambar 6 terlihat, pencapaian indeks sobek tertinggi terjadi pada kecepatan $37,5 \mathrm{~Hz}$ dengan waktu inkubasi 3-5 jam. Ini berbeda dengan waktu inkubasi untuk pencapaian indeks tarik maksimal. Tetapi pada periode 1-3 jam waktu inkubasi, indeks sobek sebenarnya sedang mengalami peningkatan pada kecepatan tersebut.

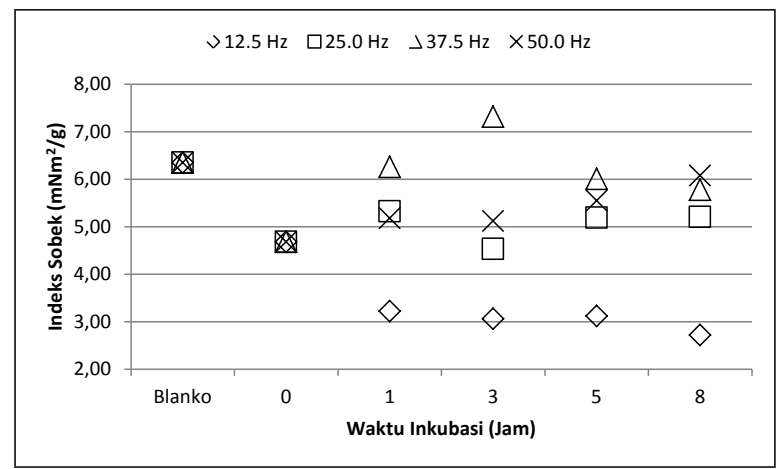

Gambar 6. Efek Inkubasi dan Agitasi terhadap Indeks Sobek 


\section{Ketahanan Lipat}

Pada periode 1 - 3 jam waktu inkubasi, nilai ketahanan lipat cenderung meningkat pada semua kecepatan (Gambar 7). Tetapi sesudah itu selanjutnya ketahanan lipat menurun. Kecenderungan pencapaian ketahanan lipat tertinggi dicapai pada kecepatan $25,0 \mathrm{~Hz}$, disusul oleh kecepatan $37,5 \mathrm{~Hz}$. Waktu inkubasi yang lebih lama, cenderung menurunkan ketahanan lipat. Kecenderungan penurunan ketahanan lipat karena adanya peningkatan sifat kekakuan serat akibat perlakuan inkubasi.

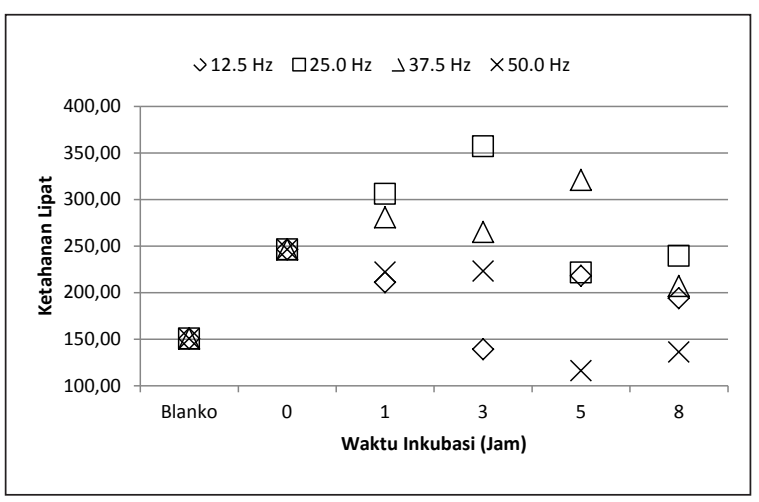

Gambar 7. Efek Inkubasi dan Agitasi terhadap Ketahanan Lipat

Saat inkubasi tumbuh fibril nanoselulosa pada permukaan serat, dan saat mengering fibril ini cenderung mengeras sehingga kertas lebih kaku. Karena kertas kaku maka pada saat dilipat kertas akan cepat patah. Peningkatan ketahanan lipat terjadi pada kecepatan agitasi 25,0 dan $37,5 \mathrm{~Hz}$. Kecepatan 12,5 dan $25,0 \mathrm{~Hz}$ adalah kecepatan laminar, sedangkan 37,5 dan $50,0 \mathrm{~Hz}$ adalah kondisi turbulen. Kondisi peralihan dari laminar ke turbulen nampaknya berkontribusi penting pada peningkatan ketahanan lipat.

\section{Porositas}

Pada perlakuan hingga 1 jam inkubasi, porositas pada semua kecepatan agitasi cenderung berkurang (Gambar 8). Selanjutnya sampai inkubasi 5 jam terjadi kecenderungan peningkatan porositas pada semua kecepatan kecuali kecepatan 50,0 Hz. Penurunan porositas hingga 1 jam perlakuan inkubasi menunjukkan bahwa matriks lembaran kertas terisi penuh oleh material halus, dalam hal ini nanoselulosa hasil produksi Acetobacter xylinum. Pada kecepatan agitasi yang turbulen yaitu 37,5 dan $50,0 \mathrm{~Hz}$, semakin lama diinkubasi maka nanoselulosa yang tumbuh pada permukaan serat kemungkinan sebagian akan terlepas kembali. Hal ini dapat mengurangi efek pengisian material halus pada matriks lembaran kertas. Oleh karena itu pada Gambar 8 terlihat adanya penurunan porositas yang lebih tajam pada kecepatan turbulen (37,5 $\mathrm{Hz}$ ) dibandingkan dengan kecepatan laminar (12,5 dan 35,0 Hz). Sementara pada kecepatan $50 \mathrm{~Hz}$ efek pengisian matriks tersebut lebih sulit hingga nilai porositasnya menjadi rendah.

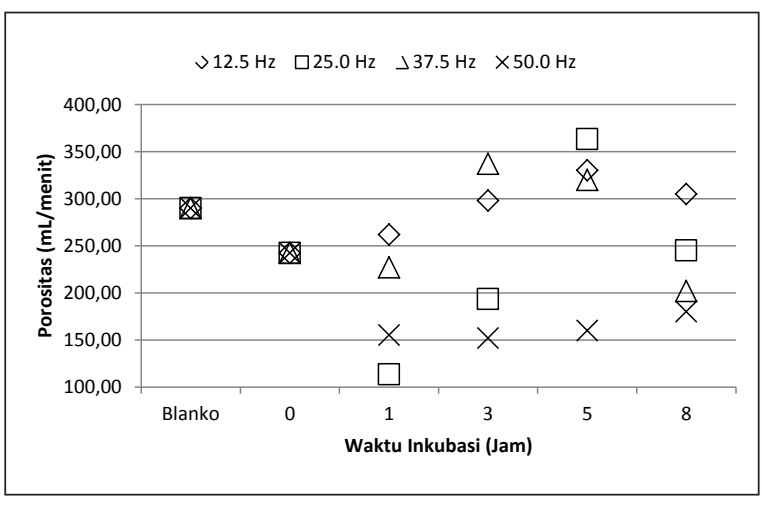

Gambar 8. Efek Inkubasi dan Agitasi terhadap Porositas

\section{Kerapatan}

Peningkatan kerapatan lembaran kertas merupakan indikasi penting daya ikat antar serat. Serat yang di refining secara intensif akan menunjukkan kerapatan yang semakin tinggi dan berpengaruh pada berbagai sifat fisik, kekuatan, dan optik lembaran. Pola kecenderungan perubahan kerapatan lembaran kertas akibat inkubasi dan kecepatan agitasi dapat dilihat pada Gambar 9.

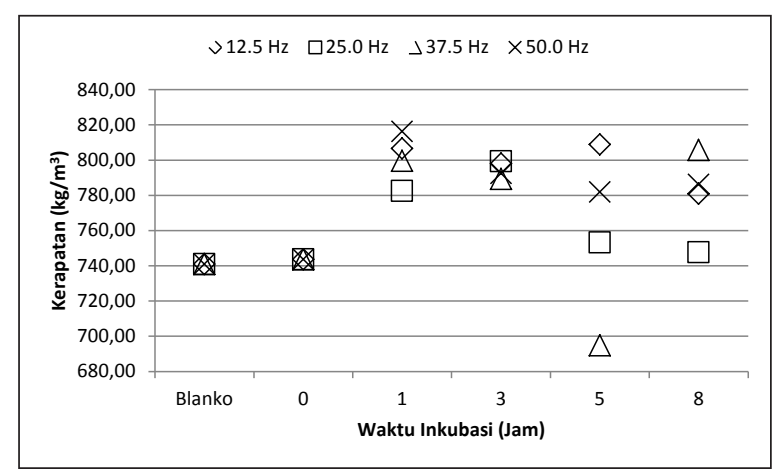

Gambar 9. Efek Inkubasi dan Agitasi terhadap Kerapatan 
Dibandingkan dengan blanko pada umumnya dapat dikatakan bahwa terjadi kecenderungan peningkatan kerapatan saat diinkubasi hingga 8 jam. Kecenderungan peningkatan porositas maksimal terjadi pada kecepatan $37,5 \mathrm{~Hz}$ dengan waktu inkubasi 2-4 jam. Peningkatan kerapatan ini juga menjadi indikasi penting bahwa ruang kosong dalam struktur matriks lembaran kertas semakin terpenuhi material dengan semakin lamanya inkubasi. Hal ini bisa terjadi karena inkubasi menumbuhkan material baru pada permukaan serat hingga kontak antar serat semakin rapat.

\section{Scattering Coefficient}

Dibandingkan dengan blanko, praktis pada semua perlakuan, Scattering Coefficient (SC) menurun dengan meningkatnya waktu inkubasi pada berbagai kecepatan agitasi (Gambar 10). Hal ini menunjukkan semakin besarnya area kontak optis antar serat. Ini menjadi indikator penting yang menunjukkan antar individu serat semakin dekat dan rapat. Berarti permukaan kontak dan ikatan antar serat semakin luas, sebagai akibat dari tumbuhnya fibril selulosa bakteri.

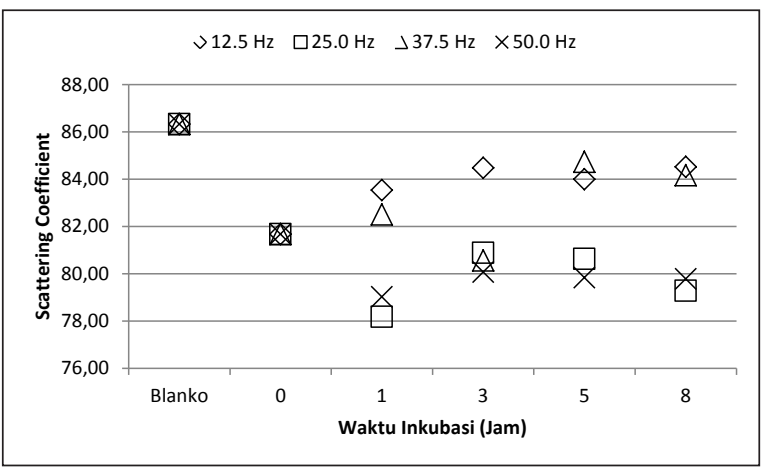

Gambar 10. Efek Inkubasi dan Agitasi terhadap Scattering Coefficient

\section{Kekasaran}

Bersama-sama dengan kerapatan dan SC, kecenderungan kekasaran juga menunjukkan tingkat kerapatan struktur permukaan kertas (Gambar 11). Adanya pertumbuhan fibril yang memperluas area kontak antar serat, sekaligus juga mengisi ruang-ruang kosong antar serat, maka permukaan serat menjadi cenderung semakin licin. Hasil di atas menunjukan semakin kecil kekasaran, semakin licin permukaan kertas.
Pencapaian kecenderungan kelicinan terbesar terjadi pada kecepatan agitasi $50,0 \mathrm{~Hz}$, sebagai akibat tercapainya distribusi yang paling merata dari massa pembentuk kertas.

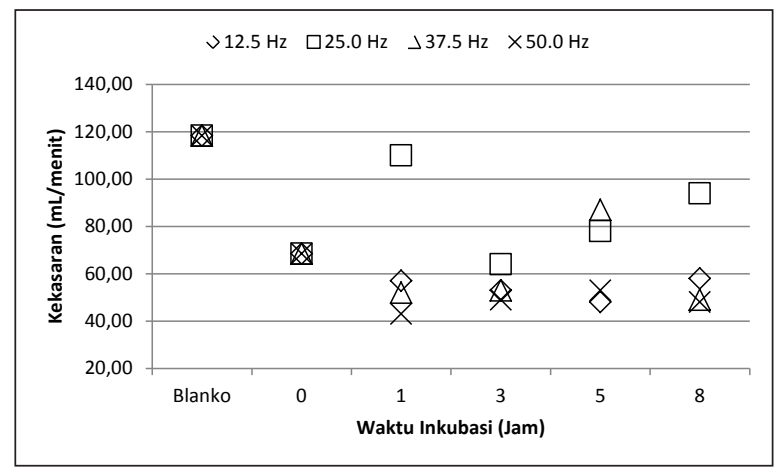

Gambar 11. Efek Inkubasi dan Agitasi terhadap Kekasaran

Untuk memudahkan melihat pengaruh kecepatan agitasi dan waktu inkubasi terhadap kualitas kertas, maka hasil-hasil pembahasan diatas dirangkum pada Tabel 1. Indikasi penghematan energi dapat diwakili oleh parameter freeness. Penghematan energi terbesar diperoleh pada penurunan freeness tertinggi yaitu pada kecepatan $25,0 \mathrm{~Hz}$ dan periode waktu inkubasi 1-3 jam. Kekuatan kertas dapat diwakili oleh indeks tarik, daya regang, TEA, indeks retak, indeks sobek dan ketahanan lipat. Maka secara umum dapat dikatakan bahwa peningkatan kekuatan kertas terjadi pada kecepatan $37,5 \mathrm{~Hz}$ dan periode waktu inkubasi 1-3 jam. Sementara itu parameter porositas, kerapatan, scattering coefficient, dan kekasaran dapat mewakili struktur lembaran kertas. Secara umum dapat dikatakan bahwa kecepatan agitasi cenderung menurunkan porositas, scattering coefficient, dan kekasaran permukaan lembaran kertas pada kecepatan agitasi $37,5 \mathrm{~Hz}$ dan waktu inkubasi $0-1$ jam. Sedangkan nilai kerapatan meningkat.

Sementara itu, parameter yang menunjukkan kondisi terbaik tidak bisa dinyatakan secara umum karena karakteristik berbagai jenis kertas berbeda, tergantung pada penggunaannya. Sebagai contoh kertas uang memerlukan ketahanan lipat yang tinggi sementara kertas cetak memerlukan scattering coefficient yang rendah. Perbaikan struktur lembaran kertas dapat diindikasikan dengan terjadinya peningkatan kerapatan, penurunan porositas, penurunan 
Tabel 1. Kecenderungan Perubahan Sifat Kertas Akibat Pengaruh Kecepatan dan Waktu

\begin{tabular}{|c|c|c|c|}
\hline No & Parameter & Kecepatan Agitasi & Waktu Inkubasi \\
\hline 1 & Freeness & $\begin{array}{l}\text { Cenderung menurun kemudian } \\
\text { meningkat, minimum pada } 25,0 \mathrm{~Hz}\end{array}$ & $\begin{array}{l}\text { Cenderung menurun kemudian } \\
\text { meningkat; minimum pada 1-3 jam }\end{array}$ \\
\hline 2 & Indeks Tarik & $\begin{array}{l}\text { Cenderung meningkat, maksimum } \\
\text { pada } 37,5 \mathrm{~Hz}\end{array}$ & $\begin{array}{l}\text { Cenderung meningkat, maksimum } \\
\text { pada } 1-3 \text { jam }\end{array}$ \\
\hline 3 & Daya Regang & $\begin{array}{l}\text { Cenderung meningkat pada } 37,5 \mathrm{~Hz} \text {, } \\
\text { lainnya konstan atau menurun }\end{array}$ & $\begin{array}{l}\text { Cenderung meningkat pada } 1-3 \text { jam } \\
\text { dan } 37,5 \mathrm{~Hz} \text {. Lainnya konstan atau } \\
\text { menurun }\end{array}$ \\
\hline 4 & $\begin{array}{l}\text { Tensile Energy } \\
\text { Absorption (TEA) }\end{array}$ & $\begin{array}{l}\text { Cenderung meningkat, maksimal } \\
\text { pada } 37,5 \mathrm{~Hz}\end{array}$ & $\begin{array}{l}\text { Cenderung meningkat, maksimal pada } \\
1-3 \text { jam }\end{array}$ \\
\hline 5 & Indeks Retak & $\begin{array}{l}\text { Cenderung meningkat pada } 12,5 \mathrm{~Hz} \\
\text { dan } 37,5 \mathrm{~Hz}\end{array}$ & $\begin{array}{l}\text { Cenderung meningkat pada } 0,5-1,5 \\
\text { jam }\end{array}$ \\
\hline 6 & Indeks Sobek & Cenderung meningkat pada $37,5 \mathrm{~Hz}$ & $\begin{array}{l}\text { Cenderung menurun, tapi meningkat } \\
\text { pada } 1-3 \text { jam, kecepatan } 37,5 \mathrm{~Hz}\end{array}$ \\
\hline 7 & Ketahanan Lipat & $\begin{array}{l}\text { Cenderung meningkat pada periode } \\
\text { awal ( } 1-3 \text { jam), maksimal pada } 25,0 \\
\text { dan } 37,5 \mathrm{~Hz}\end{array}$ & $\begin{array}{l}\text { Cenderung meningkat pada periode } \\
1-3 \text { jam kecepatan } 25,0 \text { dn } 37,5 \mathrm{~Hz}\end{array}$ \\
\hline 8 & Porositas & $\begin{array}{l}\text { Cenderung menurun pada awalnya, } \\
\text { kemudian meningkat pada } 12,5 \text { dan } \\
37,5 \mathrm{~Hz}\end{array}$ & $\begin{array}{l}\text { Cenderung menurun hingga } 1 \\
\text { jam, dan meningkat pada 3-5 jam } \\
\text { berikutnya. }\end{array}$ \\
\hline 9 & Kerapatan & $\begin{array}{l}\text { Cenderung meningkat hingga } 3 \text { jam, } \\
\text { maksimal pada } 37,5 \mathrm{~Hz}\end{array}$ & $\begin{array}{l}\text { Cenderung meningkat hingga } 3 \text { jam, } \\
\text { selanjutnya menurun }\end{array}$ \\
\hline 10 & $\begin{array}{l}\text { Scattering } \\
\text { Coefficient }\end{array}$ & Cenderung menurun & Cenderung menurun \\
\hline 11 & Kekasaran & Cenderung menurun & Cenderung menurun \\
\hline
\end{tabular}

scattering coefficient, dan penurunan kekasaran. Optimasi proses dinyatakan dalam variabel kecepatan agitasi dan waktu inkubasi.

\section{KESIMPULAN}

Bioproses modifikasi permukaan serat yang telah dilakukan berpeluang memberikan penghematan energi, peningkatan kekuatan kertas, perbaikan struktur lembaran kertas. Peningkatan kekuatan kertas dan perbaikan struktur lembaran terjadi pada kecepatan $37,5 \mathrm{~Hz}$ dan waktu inkubasi 1-3 jam. Peluang penghematan energi terbesar adalah 17,24\% diperoleh pada kecepatan agitasi $25,0 \mathrm{~Hz}$ dan waktu inkubasi 1-3 jam.

\section{SARAN}

Hasil penelitian ini perlu ditingkatkan ke skala pilot untuk mensimulasi kondisi pabrik yang sebenarnya.

\section{UCAPAN TERIMA KASIH}

Ucapan terimakasih yang sebesar-besarnya atas terselesaikannya penelitian ini, disampaikan khususnya kepada BPKIMI dan BBPK berikut seluruh anggota Tim Peneliti, serta umumnya kepada semua pihak yang secara langsung atau tidak langsung telah membantu penelitian ini.

\section{DAFTAR PUSTAKA}

Basta, A.H., El-Saied, H., 2009.Performance of Improved Bacterial Cellulose Application in the Production of Functional Paper. Journal of Applied Microbiology. Vol. 107, 20982107

Castro, C., Zuluaga, R., Alvarez, C., Putaux, J. C., Caro, G., Rojas, O. J., Mondragon, I., Ganan, P., 2012, Bacterial Cellulose produced by a new acid-resistant Gluconacetobacter genus. Carbohydrate Polymers, 89 (4), 1033-1037 
Cavka, A., Guo,X., Tang,S., Winestrand, S., Jonsson,L.J., Hong,F., 2013. Production of Bacterial Cellulose from Waste Fiber Sludge.Biotechnology for Biofules, Vol. 6, No. $25,1-10$

Chawla, R. P, Ishwar B. Bajaj, Shrikant A. Survase and Rekha S. Singha. 2009. Microbial Cellulose: Fermentative Production and Applications. Food Technol. Biotechnol. Vol. 47, No. 2, 107-124.

Chen, P., Se Youn Cho and Hyoung-Joon Jin. 2010. Review : Modification and Applications of Bacterial Celluloses in Polymer Science. Journal of Macromolecular Research. Vol.18, No.4, 309-320.

Nge, T. T., Sugiyama, J., Bulone, V., 2010. Bacterial Cellulose-Based Biomimetic Composites, Magdy Elnashar (Ed.), ISBN: 978-953-307-109-1, InTech

Pratama,Y., Salafudina, Kartasasmita, E.H., 2013. Pineaple Fruit Waste Utilization as Edible paper Aplications. International Journal of Chemical and Environmental Engineering, Vol. 4, No. 3, 171-173

Raghunathan, D., 2013. Production of Microbial Cellulose from New Bacterial Strain Isolated from Temple Wash Waters. International Journal of Current Microbiology and Applied Sciences, ISSN 2319-7706, Vol.2, No. 12, 275-290
Sani, A and Y. Dahman. 2010. Improvements in the production of bacterial synthesized biocellulose nanofibres using different culture methods. Journal of Chem Technol Biotechnol. Vol. 85, 151-164.

Surma-Slusarska, B., Presier, S., Danielewicz, D., 2008. Characteristics of Bacterial Cellulose Obtained from Acetobacter xylinum for Application in Papermaking. Fibres \& Textiles in Eastern Europe, Vol. 16, No. 4, $108-111$

Suwannapinunt, N., Burakorn, J., Thaenthanee, S., 2007. Effect of Culture Conditions on Bacterial Cellulose Production from Acetobacter xylinum TISTR976 and Physical Properties of BC Parchment Paper.Suranaree Journal of Science and Technology, Vol.14, No. 4, 357-365

Torres, F.G., Commeaux, S., Troncoso, O.P., 2012. Biocompatibility of Bacterial Cellulose Based Biomaterials. Journal of Functional Biomaterials, 3(4), 864-878

Vitta, S., Thiruvengadam, V., 2012. Multifungsional Bacterial Cellulose and Nanoparticle-embedded Composites. Curent Science, Vol. 102, No. 10, 1398-1405 
Lurnal Selulosa, Vol. 4, No. 1, Juni 2014: 47 - 56 